\title{
FORMATION OF INFRASTRUCTURAL FACTORS OF ECONOMIC DEVELOPMENT OF THE REGION
}

\author{
Ihor Zvarych ${ }^{1}$, Olena Zvarych ${ }^{2}$
}

\begin{abstract}
This article highlights the problems of determining infrastructural factors in the system of socioeconomic and cultural development of regions. Using systemic and synergetic approaches, methods of analysis and synthesis, induction and deduction, comparative analysis, it is justified that a term "infrastructure" in its modern sense is the basis of the economic system and its components, its internal organization, which guarantees its integrity. At the same time, the socio-economic meaning of the concept of "regional infrastructure" is to provide the necessary conditions for economic and social development of territories. The important role of regional infrastructure stems from its functions, which can be divided into internal (specialized) and external (regional). Internal functions are a number of important economic and social functions performed by each enterprise, and element, and subdivision of the regional infrastructure. At the same time, external ones are to ensure a comprehensive and properly balanced development of the region in accordance with its resource potential and certain specialization. In order to unconditionally improve the situation in the regional infrastructure, today many hopes of the regional and local authorities are placed on attracting external investment capital as the most promising area for financing its modernization. It is worth noting that a number of powerful foreign and domestic companies that have the appropriate experience in solving such large-scale problems are ready to become investors and implement the best achievements of organizational and technical experience in the relevant regions of Ukraine. At the same time, it is established that at this time the regions of Ukraine are trying to use their resources as efficiently as possible for further development, are looking for new opportunities to use their potential. Its disclosure and effective use, taking into account the defining regional features and the corresponding economic specialization, require a proper increase in the efficiency of all elements of the regional infrastructure. However, whatever the features of its classification, it is undeniable that it plays a key role in implementing the strategy implementation of appropriate processes of modernization of the regional economy. So, the term "infrastructure" in the modern sense is the basis of the economic system and its components, its internal organization, which guarantees its integrity. Meanwhile, the socio-economic meaning of the concept of "regional infrastructure" is to provide appropriate conditions for economic and social development of the region. Simultaneously, the more developed and modernized it is, the more attractive any unit of local self-government becomes for various investors, in particular, from the outside, which creates new jobs, reduces unemployment and increases consumer demand. In addition, today the regions of Ukraine are trying to make the most efficient use of their resources for further development, are looking for new opportunities to use their full potential. Its disclosure and effective use, taking into account regional characteristics and economic specialization, need to increase the efficiency of all elements of regional infrastructure. Contemporarily, despite the diversity of approaches to understanding its essence and the existence of different concepts, it is logical to highlight its specific levels, each of the elements of which performs its function in the economic system of the region. Therefore, the classification of regional infrastructure on a functional basis into production, social and market is the most accurate. As the analysis of its selected elements presented in this work shows, the close interrelation between them and economic development of regions is traced. The higher level of its development causes the growth of foreign investments and increase of labour resources, acceleration of economic development and growth of living standards of the population of the region. Conversely, lowering the level of infrastructural development slows down production and may lead to a decline in living standards. However, whatever the
\end{abstract}

\footnotetext{
Corresponding author:

${ }^{1}$ Vasyl Stefanyk Precarpathian National University, Ukraine.

E-mail: Zvarych2810@gmail.com

ORCID: https://orcid.org/0000-0003-2033-5054

${ }^{2}$ Vasyl Stefanyk Precarpathian National University, Ukraine.

E-mail: Lena_z@ukr.net

ORCID: https://orcid.org/0000-0002-5088-7565
} 
features of its classification, it is undeniable that it primarily plays one of the most important roles when it comes to implementing a strategy for modernization of the regional economy.

Key words: region, economic development, regional infrastructure, infrastructural provision, infrastructural objects of the territory.

\section{JEL Classification: R58}

\section{Introduction}

Infrastructure security is a necessary element of economic development of any government. Unfortunately, the state of domestic infrastructure is still far from satisfactory, which is a significant barrier to economic and social progress. Today, the regions in Ukraine are trying to make the most efficient use of all available resources for their further development, they are actively searching for new opportunities to use their potential. Analysing the global socio-economic trends, it can be argued that one of the most promising areas in this area is primarily the accelerated development of regional infrastructure and increasing the level of infrastructure security of the main components of the economic complex of the region (Adamov, 1998), which update the system of scientific research in this direction, are especially important in the construction and approval of new market forms of management in Ukraine. The number of studies and publications devoted to the proper resolution of numerous problems of individual infrastructure units at the regional level has recently increased significantly. Among domestic scientists who study such issues, it is worth noting the works by B. Adamov, V. Dorofiienko, O. Povazhnyi, K. Rybak, S. Romaniuk, H. Semchuk, Ya. Chernysh. However, such studies mainly relate to various production, technological, environmental aspects of the functioning of industrial and economic infrastructure and areas of proper development of social infrastructure and the problems of market infrastructure in Ukraine, etc., i.e. are generally fragmentary. Relevant issues of regional and local infrastructure as a complex object of influence on the economic development of the region are much less studied, which became the main task of the proposed scientific research. At the same time, issues such as the interpretation of the terms "infrastructure", "regional infrastructure", their defining functions and their classification, the development of various models of the relationship between economic development of the region and its infrastructure, and others are still insufficiently studied. The main purpose of this article is the study of these issues as key in the context of economic development of the region.

\section{Key components of the region's infrastructure}

The issues of defining regional infrastructure as a separate definition are among the current scientific problems of regional development. Clear articulation of the term "regional infrastructure" has not only academic and scientific, but also applied meaning. The term "infrastructure" in the modern sense is the basis of the economic system and its components, its internal organization, which guarantees its integrity (Chernysh, 2019). Any region is a complex and multidimensional territorial entity, which should be considered as a complex open and dynamic socio-economic system with special nature and properties. At the same time, relations in infrastructure are, in their economic essence, relations of creation of services and have a consumer character. In turn, the service that underlies the activities of the infrastructure facility is a specific economic category (Romaniuk, 2001; Semchuk, 2006), which creates the characteristic features of the infrastructure as an object of management and its modernization and reform.

The dictionary of foreign words defines the term "infrastructure" as "... a set of branches of socio-economic life, which are characterized by subordination, serve production, creating the appropriate prerequisites for the functioning of society: form the production and social infrastructure". Production includes mainly transport, communications, energy, water infrastructure, environmental protection, and primarily covers areas such as science, education, health, social protection, as well as culture and recreation (Aschauer, 1987).

Much attention in the scientific works is paid to the market component of the infrastructure based on current trends of its continuous development. Market infrastructure is a set of institutions, enterprises, organizations, and services that guarantee an acceptable regime of sustainable functioning of the market on its territory. It is clear that according to the specifics of economic activity, they can be concentrated in the cities of the region. Its market infrastructure includes financial institutions, development funds, banking institutions, audit companies, leasing, business associations, exchanges (labour, commodity stock), trading houses, information support centres, business centres, etc. The functions of market infrastructure facilities are, in particular, to provide entrepreneurs with appropriate legal and economic advice, protection of their interests, financial support and allocated credit resources, including leasing, auditing and promotion of business insurance and logistics and sales of enterprises, etc.

The socio-economic meaning of the "regional infrastructure" concept is to provide the necessary 
conditions for economic and social development of the region. At the same time, one of the most important proportions is the relationship between its production complex and infrastructure. It is on the example of various production infrastructure objects that the American economist D. Aschauer proves a direct connection between the achieved level of development of the relevant infrastructure of the region (due to certain indicators of gross infrastructure cost, dynamics of state capital investments in various infrastructure units) and the level activity of its economic component and labour productivity, the dynamics of private investment and, most interestingly, the rate of return in the private sector (Aschauer, 1987).

The important role of regional infrastructure stems from its functions, which can be divided into internal (specialized) and external (regional) (Chernysh, 2019). Internal factors mean a number of important economic and social functions performed by each enterprise, and division, and subdivision of regional infrastructure. At the same time, external ones are the provision of appropriate complex and balanced development of the region in accordance with its resource potential and predominant specialization. It is the performance of external functions and is the subject of consideration in the proposed study.

In order to unconditionally improve the situation in the infrastructure today, many hopes of regional and local authorities rely on attracting foreign investment capital as the most promising area for financing its modernization. It should be noted that a number of powerful foreign and domestic companies that have good experience in solving such largescale problems, are ready to act as investors and implement the best achievements of organizational and technical experience in different regions of Ukraine. However, there are the regions ready to embrace this experience. After all, at least in the regional infrastructure it is necessary to carry out various really effective normative and organizational, financial and economic measures.

Insufficient activity of regional authorities and local self-government is often an unresolved issue. Their passive behaviour dominates. For many regional authorities, the very violation of the essentially vital problem of finding the necessary foreign investment becomes an insurmountable challenge for the functioning of the regional mechanism. The main reason for this may be the lack of experience of government officials and their traditional mentality and lack of knowledge and skills, and often fears of competition with other regional actors for external funding. However, proper investment in regional infrastructure increases the region's importance in the external environment and the standard of living of the region's population. At the same time, such investment actions bring numerous economic and social benefits and are a potential source of its development for the region. The more developed and modernized the regional infrastructure, the more attractive the unit of local self-government becomes for investors from outside, thanks to which new jobs are created, and unemployment is reduced, and consumer demand increases. That is, the relevant infrastructure investments are among the most important "region stimulating" factors. Regional infrastructure is interpreted today as a special class of logically grouped assets that have similar physical characteristics and properties of money circulation and the same phases of development, etc. At the same time, the most important features of infrastructure assets include: rather high barriers to entry; resistance to changes in the business cycle; stable periodic cash flows with the potential for at least partial inflation indexation; relatively low correlation with other asset classes (Key World Energy Statistics).

According to the purpose of the study, we should build a model of the relationship between economic development of the region and its infrastructure. It was carried out in two stages. The first was the selection of indicators representing the production, social and market infrastructure and the indicator of economic development of the regions of Ukraine. The second solved the problem of assessing the relationship between regional infrastructure indicators and economic development of regions. As an indicator of socio-economic and cultural development of the regions of Ukraine, the indicator of gross regional product per capital was chosen. To implement the first stage, the above definitions of production, social and market infrastructure were used. Thus, let us focus on the arguments for choosing each of the indicators in more detail. The production infrastructure, in particular, includes: transport, communications and energy, as well as water infrastructure; environmental protection.

Transport infrastructure can be represented mainly by the density of transport routes or the provision of means for the carriage of goods (trucks, rail cars, river and sea vessels and aircraft) and the carriage of passengers (buses, trolleybuses, trams, subways, rail passenger cars, river, sea vessels and airplanes). In terms of ensuring European integration interests, it is not so much the quantitative assessment of the relevant transport infrastructure that comes first, but its qualitative content. Therefore, in our opinion, a more important issue is the ability to maintain the quality of such transport infrastructure, which largely depends on the optimal choice of investment funds. Therefore, to characterize transport, the relative indicator of road infrastructure restoration was chosen, which was defined as the ratio of investments in it to the average density of public roads with hard surface in each region of Ukraine.

Information on communication infrastructure in domestic statistics is represented by products (services) of mail and communication as an indicator that characterizes the volume of services provided by 
them to the population, enterprises, organizations, institutions and other consumers (sending newspapers, magazines, letters, telegrams, money transfers, pension payments, long-distance or international telephone calls) and quantitative indicators of the provision of urban and rural telephone networks, the provision of the population with broadcast radio points of sound wire broadcasting, etc. However, in today's information economy and the very rapid pace of its development, in our opinion, it is impractical to operate only with such statistical categories because taking into account advanced technologies for assessing communication infrastructure requires the use of thresholds that allow to determine the return on each additional unit of investment in infrastructure development. Therefore, it is proposed to use the indicator of marginal efficiency of investments in communication as a share of the growth of income from the provision of services in this area in the growth of capital investment in it.

Energy infrastructure is a set of sectors of the economy related to the production, transformation, transmission, and distribution of energy resources. Ukraine still does not have enough to meet its needs with its own energy resources. In this context, it is inferior to various countries of the European Union, in particular, such as Germany and France. At the same time, Ukraine has the most energy-intensive economy; the energy intensity of Ukraine's GDP is 2.6 times higher than the average energy intensity of the world's GDP (Figure 1). Such significant energy intensity is caused by an extremely high level of consumption of various energy resources per unit of output, which in turn leads to an increase in hydrocarbon imports (Key World Energy Statistics). The high energy intensity of Ukraine's GDP is mainly due to the low level of technological equipment of certain sectors of the economy, especially in the housing and communal sector, suboptimal sectoral structure of the state's economy and threatening imbalance of import-export operations, as well as the negative impact of the "shadow" economy.

One of the most important indicators of economic development of the governments is the level of electricity achieved by it. The potential of economic development of the country and its regions is indirectly determined by the volume of electricity production, in particular, per capita. Therefore, in this study, such an indicator of its production was chosen. Provision of water infrastructure is usually represented by different capacities of water supply and sewerage in the economy, which is characterized by the highest volume of water consumption (24.4\% of 5.3 billion cubic meters of total volume) (Chernysh, 2019). And a characteristic feature of the organization of water supply to the population is the dispersion of end users and the requirements for its quality. This leads to a significant increase in water supply costs. There are ongoing problems in water governance, as reformist management decisions are often opposed due to different ideological considerations. Thus, according to estimates, the centralized water supply provided water demand by $65.0 \%$, in cities by $85.0 \%$, in rural areas by $26.0 \%$ in 2000 . Of the 91 thousand $\mathrm{km}$ of pipelines (main and street) and 47 thousand $\mathrm{km}$ of

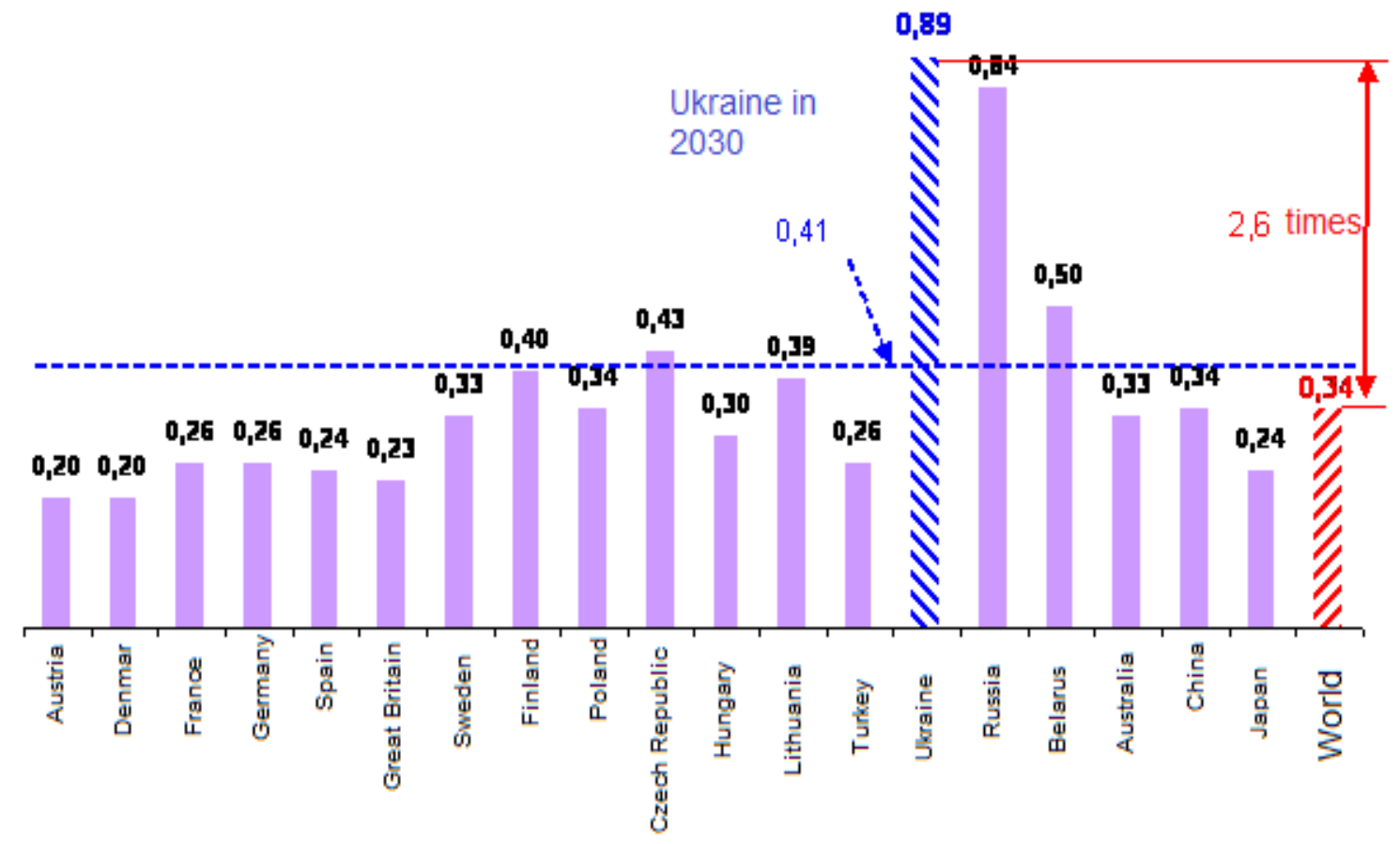

Figure 1. Energy intensity of GDP of the countries of the world / USD

Source: (Povazhnyi, 2010) 
sewage pipelines, $30.0 \%$ and $24.0 \%$, respectively, were in the state of disrepair (Chernysh, 2019). With this in mind, according to the characteristics of the water infrastructure, the provision of housing with water supply and drainage comes to the fore. Therefore, there is a need to calculate the growth rate of total drainage to increase the volume of housing.

At the same time, environmental protection is an important aspect of social activity, along with the rational (optimal) use of natural resources. It is clear that it is accompanied by significant economic costs, along with spending on health, education, culture and the arts, and so on. Activities in the field of environmental protection are considered in various aspects (economic, social, environmental, moral, technical, etc.) (Chernysh, 2019). Economic aspects are mainly related to the costs of environmental measures, taking into account the material and spiritual needs of the population and maintaining an acceptable level of quality of its environment. Therefore, it is proposed to use the indicator of marginal efficiency of investments in environmental protection as the ratio of the increase in current expenditures for protection and rational use of such resources to the growth of capital investment for their protection and efficient use.

Appropriate social infrastructure aspects for each region to cover are the following: science; education; public health; the social protection; culture and recreation. In the infrastructural aspect, science can be considered from the standpoint of scientific and scientific-technical works, which include basic and applied research, scientific-technical developments and scientifictechnical services. Each of these types of work is aimed at gaining new knowledge and their use in creating innovative products. Innovative products are divided into new for the market and new for the company. In the regional context, an innovation that is new to the market is more interesting. Here the actual regional market can be considered as a market, within which these products are produced and sold. The coefficient of efficiency of implementation of scientific developments shows the share of the volume of sold innovative products, which is new for the market in the internal current costs of scientific and scientific-technical applied developments in the region. Important components of the social infrastructure of the region, city, district, and village are focused on meeting the educational needs of families or groups living in a certain area, and educational institutions. Educational infrastructure can be represented by the number and logistics of preschool, secondary, vocational and higher education institutions of different levels of accreditation. In Ukraine at present there is a very urgent need to provide the population with preschool institutions. Therefore, this article proposes to use the indicator of coverage of children by different preschool educational institutions as the ratio of the total number of pupils of preschool educational institutions to the total number of children aged 1-6 years (excluding first grades organized in schools).

The sections of social infrastructure on health care and social protection provide indicators showing the infrastructural provision of the network of medical institutions and the network of nursing homes for the elderly and disabled in the regions of Ukraine. Hospital beds are recorded at the end of the year. They must be provided with the necessary equipment and ready to receive patients, regardless of whether they are busy or not. Nursing homes are inpatient social and medical institutions for the elderly, war and labour veterans, people with disabilities, including children with disabilities who need proper care, including medical care. In this case, the social infrastructure of culture and recreation in statistical publications is presented as information about libraries, clubs, film demonstrators and children's health and recreation facilities as permanently or temporarily functioning, specialized or adapted facilities with a specific location, facilities and available in region of human resources for the provision of appropriate services for recreation, health, physical and intellectual development of children. Children's health facilities are mostly sanatorium-type facilities, including children's centers and other out of town children's health and recreation facilities. Such children's institutions are mainly camps with day care for children and various tent camps.

One of the priority areas of state and regional policy towards children is to provide them with quality health and recreation services. Appropriate measures are aimed at improving their physical and psychological condition, improving their vitality, providing care for them and the implementation of an effective educational process and the development of intellectual and creative abilities. At the same time, the main focus is on significantly expanding the network of children's health and recreation facilities, their optimal operation during the relevant health season and providing appropriate conditions for the comprehensive development of children (especially intellectual, moral, creative and physical).

As can be seen from Figure 2, on average in the regions of Ukraine, the share of children who spent the summer in children's health and recreation facilities for the period from 2000 to 2015 was $35.5 \%$, therefore, approximately every third child aged 7 to 16 years rested and recovered in different children's institutions.

Simultaneously, the correlation coefficient between the number of children's institutions and vacationers in them is $95.6 \%$, which indicates the still insufficient provision of children with health and recreation services in Ukraine. Therefore, in this article, the indicator of providing children with health and recreation facilities is chosen as an indicator of the infrastructure of culture and recreation. 


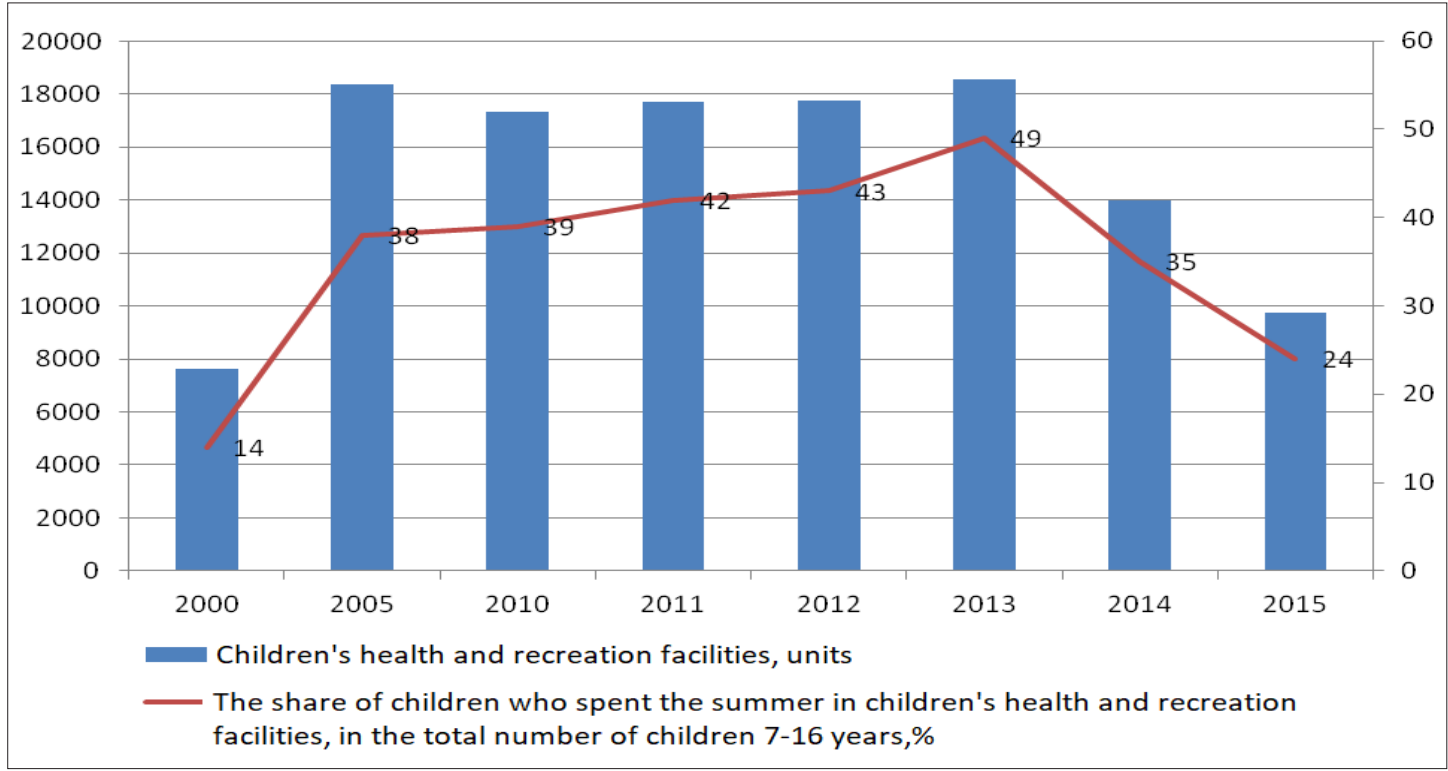

Figure 2. Indicators of providing children in different regions of Ukraine with health and recreation services Source: (Aschauer, 1987)

The market infrastructure includes: trade; financial and insurance activities; real estate transactions; activities in the field of administrative or support services; other types of economic activity. Each of these types of market infrastructure plays a role in public life and development of the region. At the same time, they are united by the fact that they are needed by all activities and the population of the region without exception. In the meantime, market infrastructure is an effective mechanism for entrepreneurship, covering a wide range of economic processes (from production to consumption), including: contracting for supply and organization of material flows between industries and regions and sales management and proper service. In this regard, the efficiency of the regional economy depends primarily on the complexity and efficiency of the market infrastructure achieved in the region.

An integral part of the market infrastructure is the trade infrastructure, which includes a set of special formations (organizations, commercial and trade institutions, establishments, enterprises, services), each of which plays a role in organizing the process of wholesale and retail sales of goods and services. Infrastructural formations of trade do not have the main purpose of carrying out own commercial activity, instead they should provide conditions for optimum and effective carrying out of commercial activity by various subjects of the basic structure of trade. Coincidently, its main elements are divided into two groups according to their main functional purpose: a group of elements of the main (internal) and a group of general market (external) infrastructure. The elements of the internal infrastructure of trade include such divisions of the trade network as shops (in particular, pharmacies), gas stations, kiosks, tents, trays, online stores and relevant postal order firms. The efficiency of the trade network is determined by the volume of its retail turnover - the index of its physical volume. Moreover, the retail trade turnover includes the retail turnover of enterprises engaged in retail trade and the estimated sales of various goods through a certain trade network owned by individual entrepreneurs, as well as in the markets.

Financial market infrastructure includes entities and elements that create organizational and economic preconditions for financial market participants, ensuring proper coherence and coordination of their joint actions, improving the efficiency of financial operations and the functioning of the market mechanism as a whole. The infrastructure of the financial and insurance market can include various institutions that are financial intermediaries or supporting institutions. In particular, it is: “...institutions of intermediary financial nature issuing, commercial, investment, mortgage, savings and foreign trade banks and specialized non-bank financial and credit organizations. These include insurance, investment, financial, pension funds, credit unions, savings institutions, pawnshops, leasing, factoring, trust companies that are professional market players, traders in securities and other financial market instruments and underwriters; relevant trade organizer stock and currency exchanges, over the counter stock trading systems; intermediaries in trade agreements-brokers and dealers; national depository system, depositories, clearing depositories; custodians and registrars of securities; settlement and clearing banks; information and analytical institutes, consulting centers; various self-regulatory organizations of the financial services 
market". At the same time, the infrastructure of the financial and insurance market is a component of the financial and insurance activity of the regional economy, which is created in order to serve the financial and insurance market, ensuring its normal functioning. The efficiency of its use is directly related to the achieved profitability in financial and insurance activities, which can be represented by the profitability of financial and insurance activities, calculated as the ratio of profits from it to the total amount of various costs and contributions of financial and insurance companies.

The infrastructure of enterprises in the field of real estate transactions is formed by real estate agencies (real estate companies). As stated in (Chernysh, 2019), “... real estate activity is a business activity related to real estate transactions. Such transactions include: trade in real estate, including the sale of real estate by public auction; real estate brokerage; related information and consulting activities". As an indicator of the efficiency of the use of the infrastructure of real estate agencies, the indicator of their profitability was chosen the profitability of enterprises in the field of real estate transactions. Infrastructure of enterprises and organizations in the field of administrative and support services. "Activities in the field of administrative and support services are activities to support the main activities of enterprises, which include: rent, hire, leasing; employment work; activities of travel agencies, tour operators, reservation services and related activities; activities of security services, investigations; maintenance of buildings or territories; administrative and support office activities and other ancillary commercial services". As in the previous case, it is proposed to use the profitability indicator in the field of administrative and support services. Infrastructure of public, extraterritorial organizations, and bodies, and other types of market infrastructure is characterized by profitability. The set of selected indicators representing the production, social and market infrastructure and the methodological approach to their calculation and the units of their measurement are given in Table 1 .

In the second stage, you should choose a method of assessing the relationship between indicators of production, social, and market infrastructure and the indicator of economic development of regions. After the formation of their totality, their calculation is carried out on the basis of real statistical data of the Statistics Service and other necessary information materials. Since the generated statistical population is heterogeneous in units of measurement, the next step is the standardization (normalization) of data. In accordance with it, we get the "new" statistics we need as conditional values.

The choice of the appropriate method for assessing the relationship between indicators of production, social and market infrastructure and the indicator of economic development of regions is based on the theory of mathematical statistics, which suggests using correlation analysis or the theory of metrics (distance) for such analysis. These types of analysis are essentially similar, but opposite in conclusion. Thus, based on the definition of correlation and determination coefficients, it is possible to establish the real closeness of the linear relationship between indicators, and the closer their absolute value is to 1 , the closer the relationship is, and conversely, the closeness of the absolute estimate to 0 indicates no relationship between selected indicators.

Measures of distance provide a real opportunity to draw opposite conclusions the smaller the distance between the indicators, the closer the relationship between them, and vice versa. The proposed study focuses primarily on the second approach. In this case, when choosing the metric of the distance between Euclidean, Manhattan, Mikhnovsky and others, we dwell on the Euclidean distance, which is determined by the formula:

$$
O_{i, G R P}=\sqrt{\sum_{t=1}^{T}\left(x_{i t}-x_{G R P t}\right)^{2}},
$$

where $O_{i, G R P}$ is the distance between the $i$-th indicator of infrastructure and the indicator of economic development in the period $t$;

$x_{i t}$ is the value of the $i$-th infrastructure indicator in the period $t$;

$x_{G R P t}$ is the value of the indicator of economic development in the period $t$.

\section{Comparative characteristics of the regions}

For the purpose of analysis, statistical information of the State Statistics Service of Ukraine for 20082018 was used (Aschauer, 1987). Due to hostilities in Donetsk and Luhansk and the annexation of the Autonomous Republic of Crimea for 2014-2016, there are no statistics on the Autonomous Republic of Crimea, the city of Sevastopol and the abovementioned regions.

The results of the calculation of Euclidean distances between the indicators of production infrastructure and the GRP per capita are shown in Table 2.

As can be seen from Table 2, between the indicator of transport infrastructure we trace a close communication in Donetsk, Zhytomyr, Zakarpattia, Zaporizhzhia, Ivano-Frankivsk, Poltava and Kherson regions. Instead, in the Autonomous Republic of Crimea, Dnipropetrovsk, Kyiv, Lviv, Odesa, Rivne, Kharkiv, Chernihiv regions, such factor has no impact on the GRP of the region. And in Ukraine as a whole, the link between GDP and the pace of road infrastructure recovery is weak.

The indicator of marginal efficiency of investment in communication is closely correlated with GRP in Volyn, 
Table 1

The set of indicators representing the production, social and market infrastructure of the regions of Ukraine

\begin{tabular}{|c|c|c|c|}
\hline No. & Infrastructure & Indicator & Unit of measurement \\
\hline \multicolumn{4}{|c|}{ Production infrastructure } \\
\hline 1.1 & Transport & $\begin{array}{l}\text { Road infrastructure recovery ratio = investment in road infrastructure / density } \\
\text { of paved public roads }\end{array}$ & $\begin{array}{l}\text { million UAH / km per } \\
1000 \text { sq. } \mathrm{km} \text { of territory }\end{array}$ \\
\hline 1.2 & Communication & $\begin{array}{l}\text { Marginal efficiency of communication investments = increase in revenues from } \\
\text { the provision of communication services / increase in capital investment in its } \\
\text { development }\end{array}$ & percent \\
\hline 1.3 & Energy sector & Electricity production per capita & million $\mathrm{kW} \cdot \mathrm{h} . /$ pers. \\
\hline 1.4 & Water infrastructure & The growth rate of total drainage to the growth of housing & percent \\
\hline 1.5 & Environmental protection & $\begin{array}{l}\text { Marginal efficiency of investments in environmental protection = increase in } \\
\text { current expenditures for protection and rational use of natural resources / increase } \\
\text { in capital investments in protection and rational use of relevant natural resources }\end{array}$ & percent \\
\hline \multicolumn{4}{|c|}{ Social infrastructure } \\
\hline 2.1 & Science & $\begin{array}{l}\text { Coefficient of efficiency of implementation of scientific developments = volume } \\
\text { of the realized innovative production which is new for the market / internal } \\
\text { current expenses for scientific and various scientific, and technically applied, } \\
\text { and some other developments }\end{array}$ & shares \\
\hline 2.2 & Education & $\begin{array}{l}\text { Preschool enrolment rate }=\text { total number of preschool pupils / total number } \\
\text { of children aged 1-6 (excluding children enrolled in the first forms, which are } \\
\text { usually organized in the respective schools) }\end{array}$ & percent \\
\hline 2.3 & Medicare & Provision of the population with hospital beds & $\begin{array}{l}\text { number of beds/ } \\
10 \text { thousand population }\end{array}$ \\
\hline 2.4 & Social protection & $\begin{array}{l}\text { Number of nursing homes for the elderly and disabled (adults, and children, } \\
\text { and youth) }\end{array}$ & units \\
\hline 2.5 & Culture and recreation & Children's health and recreation facilities & units \\
\hline \multicolumn{4}{|c|}{ Market infrastructure } \\
\hline 3.1 & Trade & Index of physical volume in the field of retail trade & percent \\
\hline 3.2 & $\begin{array}{l}\text { Financial and insurance } \\
\text { activities }\end{array}$ & Profitability of financial and insurance activities & percent \\
\hline 3.3 & Real estate transactions & Profitability of enterprises in the field of real estate transactions & percent \\
\hline 3.4 & $\begin{array}{l}\text { Activities in the field } \\
\text { of administrative and } \\
\text { support services }\end{array}$ & Profitability of activities in the field of administrative and support services & percent \\
\hline 3.5 & $\begin{array}{l}\text { Other activities (activities } \\
\text { of public, extraterritorial } \\
\text { organizations and bodies) }\end{array}$ & Profitability of other activities & percent \\
\hline
\end{tabular}

Dnipropetrovsk, Zhytomyr, Zakarpattia, Zaporizhzhia, Ivano-Frankivsk, Kirovohrad, Luhansk, Lviv, Mykolaiv, Poltava, Sumy, Kharkiv, Kherson, Khmelnytskyi, Chernivtsi regions. Weak communication is in the Autonomous Republic of Crimea and Sevastopol. Electricity generation and GRP are closely linked in Vinnytsia, Dnipropetrovsk, Donetsk, Zhytomyr, Zakarpattia, Zaporizhzhia, Ivano-Frankivsk, Kyiv, Luhansk, Lviv, Mykolaiv, Odesa, Rivne, Ternopil, Chernivtsi, and Chernihiv regions, only in the city of Sevastopol. The same characteristics are inherent in the relationship of water and environmental infrastructure with economic development. At the same time, all regions showed a close correlation between them, except for the Autonomous Republic of Crimea and the city of Sevastopol (see Table 2).

The same pattern can be traced for the average indicator of production infrastructure as a close relationship between the indicators, except for the Autonomous Republic of Crimea and the city of Sevastopol. Allocation of economic entities to a separate subdivision of production infrastructure is important primarily from the standpoint of efficient use of communal (common) property at the regional level, as a significant number of them belong to the communal form of ownership, and to increase business activity in the region. As can be seen from the average indicator of production infrastructure, the activities of various production and infrastructure facilities of the Autonomous Republic of Crimea and the city of Sevastopol are really unable to provide the necessary conditions for the organization of entrepreneurship.

The results of the calculation of Euclidean distances between the indicators of social infrastructure and the GRP per capita are shown in Table 3.

Here, as well as in the production infrastructure of the region, different results are shown. However, it is 
Vol. 7, No. 1, 2021

Table 2

Assessment of the relationship between socio-economic development of the region and its production infrastructure

\begin{tabular}{|c|c|c|c|c|c|c|}
\hline Region & Transport & Communication & Energy sector & $\begin{array}{c}\text { Water } \\
\text { infrastructure }\end{array}$ & $\begin{array}{c}\text { Environmental } \\
\text { protection }\end{array}$ & $\begin{array}{c}\text { Production } \\
\text { infrastructure }\end{array}$ \\
\hline Ukraine & 3.64 & 3.84 & 3.04 & 3.34 & 3.93 & 3.56 \\
\hline AR Crimea & 4.83 & 9.21 & 3.30 & 10.56 & 9.68 & 7.52 \\
\hline Vinnytsia & 2.45 & 4.05 & 1.41 & 3.48 & 3.16 & 2.91 \\
\hline Volyn & 3.09 & 3.49 & 4.41 & 3.53 & 1.09 & 3.12 \\
\hline Dnipropetrovsk & 4.03 & 3.16 & 2.76 & 2.61 & 3.76 & 3.26 \\
\hline Donetsk & 1.31 & 4.12 & 2.07 & 2.30 & 3.70 & 2.70 \\
\hline Zhytomyr & 0.78 & 2.70 & 2.63 & 3.81 & 2.32 & 2.45 \\
\hline Zakarpattia & 1.94 & 3.55 & 3.21 & 2.53 & 2.46 & 2.74 \\
\hline Zaporizhzhia & 1.04 & 2.59 & 2.42 & 2.64 & 3.75 & 2.49 \\
\hline Ivano-Frankivsk & 1.61 & 2.69 & 2.06 & 3.14 & 1.84 & 2.27 \\
\hline Kyiv & 3.99 & 4.13 & 2.84 & 3.33 & 2.56 & 3.37 \\
\hline Kirovohrad & 2.85 & 3.45 & 3.67 & 3.38 & 3.89 & 3.45 \\
\hline Luhansk & 2.75 & 1.29 & 2.93 & 2.16 & 3.80 & 2.59 \\
\hline Lviv & 4.03 & 1.57 & 2.82 & 3.11 & 4.20 & 3.15 \\
\hline Mykolaiv & 1.01 & 1.59 & 3.05 & 2.63 & 2.44 & 2.14 \\
\hline Odesa & 4.12 & 3.82 & 1.24 & 3.60 & 2.70 & 3.10 \\
\hline Poltava & 2.03 & 3.15 & 4.30 & 3.68 & 2.98 & 3.23 \\
\hline Rivne & 3.69 & 4.37 & 2.25 & 2.71 & 1.60 & 2.93 \\
\hline Sumy & 2.68 & 2.90 & 3.93 & 2.71 & 3.36 & 3.12 \\
\hline Ternopil & 2.57 & 4.10 & 3.04 & 3.38 & 3.74 & 3.37 \\
\hline Kharkiv & 3.75 & 1.10 & 3.86 & 2.84 & 4.20 & 3.15 \\
\hline Kherson & 1.15 & 3.18 & 4.05 & 3.36 & 3.71 & 3.09 \\
\hline Khmelnytskyi & 2.54 & 2.79 & 3.62 & 3.31 & 3.77 & 3.21 \\
\hline Cherkasy & 2.40 & 4.33 & 2.78 & 3.55 & 2.96 & 3.20 \\
\hline Chernivtsi & 2.36 & 0.72 & 2.78 & 3.31 & 3.56 & 2.55 \\
\hline Chernihiv & 3.91 & 3.99 & 3.31 & 3.37 & 3.17 & 3.55 \\
\hline Kyiv (city) & * & 3.92 & 4.29 & 2.04 & 4.22 & 3.62 \\
\hline Sevastopol & * & 9.04 & 7.36 & 11.18 & 10.95 & 9.63 \\
\hline
\end{tabular}

* - no data available

\begin{tabular}{|l|l|l|}
\hline weak communication & moderate communication & close communication \\
\hline
\end{tabular}

worth noting the weak communication for all categories of social infrastructure with GRP for the Autonomous Republic of Crimea, moderate and weak for all categories of social infrastructure with GRP for Sevastopol. When determining the communication between the average assessment of social infrastructure and GRP, there is a moderate communication in Donetsk and Luhansk regions, which is absent in the Autonomous Republic of Crimea and the city of Sevastopol.

As noted in (Povazhnyi, 2010), in the socioeconomic and cultural development of the region, social infrastructure performs important functions, in particular: demographic (preservation and improvement of the health of the population of the region and creation of positive conditions for significant improvement of the demographic situation in the region, which is especially relevant in the Ukrainian regions); reproduction of labour and human potential in general; recreational (significant increase in free time of residents, promoting its rational use); raising the level and improving the employment structure of the region's population; formation of personality, public consciousness; increasing the level of activity of each territorial community.

However, for regions that do not have a close link between infrastructure and economic development, such functions cannot be fully performed. The results of the calculation of Euclidean distances between the indicators of the regional market infrastructure and the GRP per capita of the region are shown in Table 4.

Table 4 shows that weak communications can be traced between market infrastructure and economic development in the Autonomous Republic of Crimea and Sevastopol. In terms of "Financial and insurance activities" and economic development of the region, we have moderate communications for most of them. All other components and generalized characteristics of the region's infrastructure indicate close links between market infrastructure and the region's economic development. This once again confirms the 
Table 3

Assessment of the relationship between the economic development of the region and its social infrastructure

\begin{tabular}{|c|c|c|c|c|c|c|}
\hline Region & Science & Education & Medicare & Social protection & $\begin{array}{l}\text { Culture and } \\
\text { recreation }\end{array}$ & $\begin{array}{c}\text { Social } \\
\text { infrastructure }\end{array}$ \\
\hline Ukraine & 4.30 & 2.86 & 4.38 & 4.29 & 4.30 & 4.03 \\
\hline AR Crimea & 7.75 & 45.22 & 86.68 & 21.43 & 9.12 & 34.04 \\
\hline Vinnytsia & 2.02 & 1.06 & 4.35 & 3.92 & 4.39 & 3.15 \\
\hline Volyn & 4.11 & 1.06 & 4.34 & 3.97 & 4.31 & 3.56 \\
\hline Dnipropetrovsk & 3.35 & 1.41 & 4.18 & 4.00 & 3.96 & 3.38 \\
\hline Donetsk & 4.21 & 17.03 & 59.54 & 0.89 & 1.47 & 16.63 \\
\hline Zhytomyr & 0.83 & 1.59 & 4.24 & 2.11 & 4.37 & 2.63 \\
\hline Zakarpattia & 2.92 & 1.64 & 4.41 & 4.06 & 4.18 & 3.44 \\
\hline Zaporizhzhia & 3.88 & 1.63 & 4.15 & 1.08 & 4.19 & 2.99 \\
\hline Ivano-Frankivsk & 4.29 & 0.54 & 4.38 & 1.40 & 4.19 & 2.96 \\
\hline Kyiv & 3.50 & 0.71 & 4.44 & 2.44 & 4.30 & 3.08 \\
\hline Kirovohrad & 2.31 & 1.30 & 4.18 & 2.07 & 4.07 & 2.78 \\
\hline Luhansk & 1.97 & 16.90 & 26.37 & 0.52 & 1.07 & 9.37 \\
\hline Lviv & 3.52 & 0.99 & 4.44 & 1.97 & 4.04 & 2.99 \\
\hline Mykolaiv & 3.45 & 1.63 & 3.95 & 2.23 & 4.42 & 3.14 \\
\hline Odesa & 4.23 & 1.54 & 4.27 & 3.90 & 4.41 & 3.67 \\
\hline Poltava & 4.32 & 1.86 & 4.25 & 2.23 & 4.41 & 3.42 \\
\hline Rivne & 0.81 & 1.66 & 4.20 & 3.94 & 4.21 & 2.97 \\
\hline Sumy & 2.22 & 1.16 & 4.34 & 2.10 & 3.59 & 2.68 \\
\hline Ternopil & 3.60 & 0.94 & 4.12 & 1.92 & 4.13 & 2.94 \\
\hline Kharkiv & 3.18 & 1.39 & 4.34 & 2.11 & 4.42 & 3.09 \\
\hline Kherson & 4.16 & 2.08 & 4.30 & 2.22 & 4.32 & 3.42 \\
\hline Khmelnytskyi & 3.47 & 1.00 & 4.25 & 2.18 & 4.39 & 3.06 \\
\hline Cherkasy & 3.01 & 1.51 & 4.23 & 3.95 & 4.34 & 3.41 \\
\hline Chernivtsi & 4.20 & 1.64 & 4.29 & 1.89 & 4.14 & 3.23 \\
\hline Chernihiv & 2.11 & 1.10 & 4.40 & 3.98 & 4.35 & 3.19 \\
\hline Kyiv (city) & 3.83 & 0.78 & 4.43 & 3.76 & 4.36 & 3.43 \\
\hline Sevastopol & 9.58 & 43.00 & 225.76 & 7.13 & 4.41 & 57.98 \\
\hline
\end{tabular}

fact that market conditions in Ukraine encourage the transformation of market infrastructure from a passive satellite of production, which it was in the days of command and control economy, into an equal partner of the real sector, transforming into an open sphere of activity, which ensures the effective functioning of the entire economy, creating a logistical, organizational and financial-economic basis for its development. Figure 3 shows the relationship of production, social and infrastructure of the region as a whole with GRP. As can be seen from it, the relationship between the indicators selected for analysis is underdeveloped in the Autonomous Republic of Crimea and Sevastopol, Donetsk and Luhansk regions. Despite the diversity of approaches to understanding the essence of regional infrastructure and the existence of relevant concepts, it is logical to distinguish its different levels, each of the elements of which performs its function in the economic system of the region. Therefore, the classification of regional infrastructure on a functional basis into production, social and market is, in our opinion, the most accurate. As shown in the analysis of its selected elements, there is a close communication between them and the economic development of the regions.

The higher level of its development causes a certain increase in investment and some increase in labour resources, accelerating the pace of economic development and rising living standards of the region's residents. Conversely, lowering the level of regional infrastructure development slows down production and may lead to a certain decline in living standards in the country.

It is worth noting that the regional infrastructure does not function separately. It should be proportional to the level of development of production and circulation at each stage of development of society. After all, the modern economy requires powerful industrial and commercial complexes, a network of relevant facilities for logistics of production and circulation, information and commercial networks, highly efficient means of financial institutions and settlements, and the population of the region must be provided with high quality educational, medical and cultural educational services. At the same time, the development of regional 
Vol. 7, No. 1, 2021

Baltic Journal of Economic Studies

Table 4

Assessment of the relationship between the economic development of the region and its market infrastructure

\begin{tabular}{|c|c|c|c|c|c|c|}
\hline Region & Trade & $\begin{array}{c}\text { Financial and } \\
\text { insurance } \\
\text { activities }\end{array}$ & $\begin{array}{l}\text { Real estate } \\
\text { transactions }\end{array}$ & $\begin{array}{c}\text { Activities in } \\
\text { the field of } \\
\text { administrative and } \\
\text { support services }\end{array}$ & $\begin{array}{c}\text { Other } \\
\text { activities }\end{array}$ & $\begin{array}{c}\text { Market } \\
\text { infrastructure }\end{array}$ \\
\hline Ukraine & 4.35 & 4.07 & 4.12 & 4.18 & 2.86 & 3.91 \\
\hline AR Crimea & 10.94 & 7.80 & 8.94 & 8.30 & 9.60 & 9.12 \\
\hline Vinnytsia & 4.43 & 3.09 & 3.55 & 2.26 & 4.10 & 3.49 \\
\hline Volyn & 4.21 & 3.56 & 3.34 & 3.78 & 1.17 & 3.21 \\
\hline Dnipropetrovsk & 4.38 & 4.37 & 4.03 & 2.60 & 2.05 & 3.49 \\
\hline Donetsk & 1.59 & 3.95 & 1.74 & 1.60 & 1.57 & 2.09 \\
\hline Zhytomyr & 4.39 & 1.28 & 4.15 & 1.47 & 1.19 & 2.50 \\
\hline Zakarpattia & 4.40 & 1.85 & 4.27 & 3.50 & 4.36 & 3.68 \\
\hline Zaporizhzhia & 4.43 & 3.54 & 4.26 & 0.82 & 2.71 & 3.15 \\
\hline Ivano-Frankivsk & 4.19 & 4.04 & 3.28 & 4.02 & 3.98 & 3.90 \\
\hline Kyiv & 4.08 & 3.27 & 4.06 & 3.80 & 3.54 & 3.75 \\
\hline Kirovohrad & 4.41 & 4.25 & 1.53 & 3.53 & 2.55 & 3.26 \\
\hline Luhansk & 0.83 & 2.88 & 1.45 & 3.02 & 3.98 & 2.43 \\
\hline Lviv & 4.30 & 3.72 & 1.91 & 3.55 & 3.93 & 3.48 \\
\hline Mykolaiv & 4.36 & 3.85 & 4.10 & 3.87 & 4.23 & 4.08 \\
\hline Odesa & 4.33 & 3.60 & 4.16 & 1.35 & 2.77 & 3.24 \\
\hline Poltava & 4.39 & 3.16 & 3.72 & 4.21 & 1.48 & 3.39 \\
\hline Rivne & 4.24 & 2.49 & 3.71 & 1.36 & 3.56 & 3.07 \\
\hline Sumy & 4.28 & 3.06 & 1.84 & 1.84 & 2.55 & 2.71 \\
\hline Ternopil & 4.33 & 3.87 & 2.20 & 3.04 & 1.85 & 3.06 \\
\hline Kharkiv & 4.34 & 3.49 & 4.15 & 2.56 & 4.31 & 3.77 \\
\hline Kherson & 4.33 & 0.77 & 4.04 & 2.45 & 3.99 & 3.11 \\
\hline Khmelnytskyi & 4.39 & 3.80 & 3.20 & 4.14 & 2.06 & 3.52 \\
\hline Cherkasy & 4.44 & 4.16 & 3.11 & 2.20 & 3.91 & 3.57 \\
\hline Chernivtsi & 4.32 & 4.04 & 3.90 & 2.86 & 1.25 & 3.27 \\
\hline Chernihiv & 4.29 & 3.75 & 2.14 & 1.48 & 2.63 & 2.86 \\
\hline Kyiiv (city) & 4.41 & 3.68 & 4.20 & 4.42 & 3.43 & 4.03 \\
\hline Sevastopol & 18.62 & 9.90 & 12.38 & 11.21 & 10.10 & 12.24 \\
\hline
\end{tabular}

infrastructure becomes especially important for the economy of the region, and recently for the amalgamated territorial communities.

\section{Conclusions}

The term "infrastructure" in the modern sense is the basis of the economic system and its components, its internal organization, which guarantees its integrity. Meanwhile, the socio-economic meaning of the concept of "regional infrastructure" is to provide appropriate conditions for economic and social development of the region. Simultaneously, the more developed and modernized it is, the more attractive any unit of local self-government becomes for various investors, in particular, from the outside, which creates new jobs, reduces unemployment and increases consumer demand. In addition, today the regions of Ukraine are trying to make the most efficient use of their resources for further development, are looking for new opportunities to use their full potential. Its disclosure and effective use, taking into account regional characteristics and economic specialization, need to increase the efficiency of all elements of regional infrastructure. Contemporarily, despite the diversity of approaches to understanding its essence and the existence of different concepts, it is logical to highlight its specific levels, each of the elements of which performs its function in the economic system of the region. Therefore, the classification of regional infrastructure on a functional basis into production, social and market is the most accurate. As the analysis of its selected elements shown in this work shows, the close interrelation between them and economic development of regions is traced. The higher level of its development causes the growth of foreign investments and increase of labour resources, acceleration of economic development and growth of living standards of the population of the region. Conversely, lowering the level of infrastructural 


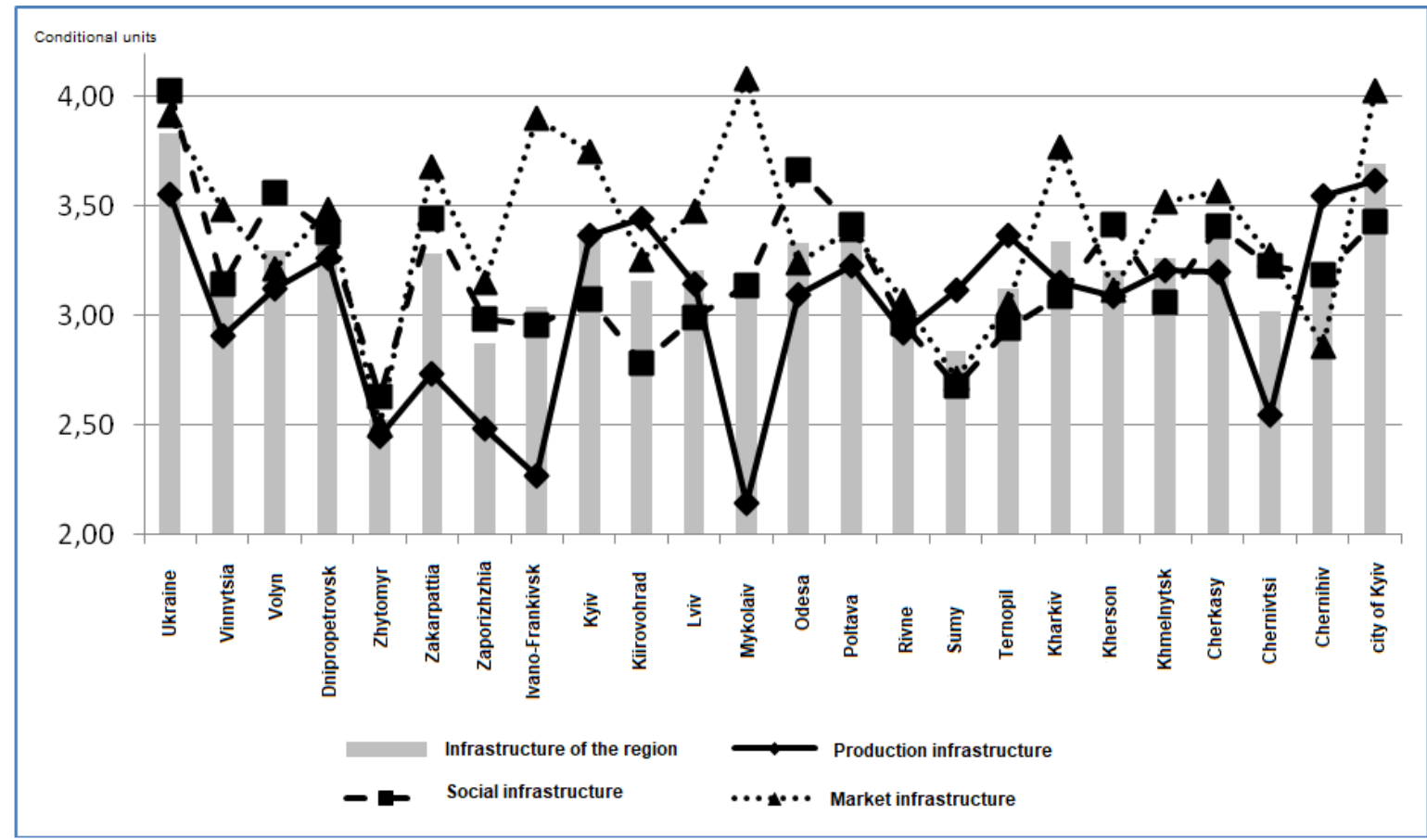

Figure 3. The relationship between production, social, market, and infrastructure in general with GRP

development slows down production and may lead to a decline in living standards. However, whatever the features of its classification, it is undeniable that it primarily plays one of the most important roles when it comes to implementing a strategy for modernization of the regional economy.

\section{References:}

Adamov, B. I. (1998). Orhanizatsiino-ekonomichni osnovy upravlinnia rozvytkom mist [Organizational and economic bases of urban development management]. Kyiv: Hrot. (in Ukrainian)

Dorofienko, V. V. (2012). Poisk upravlencheskikh reshenii reformirovaniia ZhKKh (na primere opyta Ukrainy i Rossii) [Search for management solutions for reforming housing and communal services (based on the experience of Ukraine and Russia)]. Bulletin of Khmelnytskyi National University, vol. 4, no. 3. Khmelnytskyi: KhNU Publishing House. (in Russian)

Povazhnyi, O. S. (2010). Naukovi zasady reformuvannia i rozvytku zhytlovo-komunalnoho hospodarstva: monohrafiia [Scientific principles of reforming and development of housing and communal services: monograph]. State University of Management. Cherkasy: Brama Ukraina. (in Ukrainian)

Rybak, K. O. (2018). Mistobudivna diialnist yak obiekt administratyvno-pravovoho rehuliuvannia: monohrafiia [Urban planning activity as an object of administrative and legal regulation: monograph]. Taras Shevchenko National University of Kyiv. Kyiv: Publishing House "Helvetica". (in Ukrainian)

Romaniuk, S. (2001). Polityka rehionalnoho rozvytku v Ukraini: suchasnyi stan i novi mozhlyvosti [Regional development policy in Ukraine: current status and new opportunities]. Kyiv: UADU. (in Ukrainian)

Semchuk, H. M. (2006). Stan realizatsii derzhavnoi polityky enerhozberezhennia u sferi zhytlovo-komunalnoho hospodarstva [The state of implementation of the state energy saving policy in the field of housing and communal services]. Procedings of the International Congress "Institutional and technical aspects of housing and communal services reform". Kyiv. (in Ukrainian)

Chernysh, Ya. (2019). Udoskonalennia orhanizatsii nadannia administratyvnykh posluh orhanamy mistsevoho samovriaduvannia [Improving the organization of administrative services by local governments]. Kharkiv. (in Ukrainian) Zvarych, I. T., \& Zvarych, O. I. (2018). Suchasni zasoby efektyvnoho upravlinnia zhytlovo-komunalnym kompleksom rehionu [Modern means of effective management of housing and communal services of the region]. Modeling of the regional economy. Collection of scientific works, vol. 1(31). Ivano-Frankivsk: Plai. (in Ukrainian)

Reforma haluzi vodopostachannia ta vodovidvedennia v Ukraini [Reform of water supply and sewerage in Ukraine]. Available at: http://www.ier.com.ua/files/publications/Policy_papers/German_advisory_group/2003/S23_ ukr.pdf (accessed 27 February 2021).

Aschauer, D. (1987). Is the Public Capital Stock Too Low? Chicago Fed Letter. October.

Key World Energy Statistics. Available at: https://www.iea.org/publications/freepublications/publication/keyworld-energy-statistics.html (accessed 12 January 2021). 